\title{
ANALISA KELAYAKAN INVESTASI SPBU MIKROSITE INDOMOBIL DI DESA GRAJAGAN
}

\author{
Hendra Bhakti ${ }^{1)}$, Bela Iwari Setiawan $\varpi^{2)}$, dan Wisudanto Mas Soeroto $\varpi^{3)}$ \\ ${ }^{1,2}$ Magister Manajemen Teknologi, Institut Teknologi Sepuluh Nopember \\ ${ }^{3}$ Departemen Manajemen, Universitas Airlangga, Surabaya \\ ${ }^{1,2}$ Jl. Teknik Kimia, Keputih, Kec. Sukolilo, Surabaya, 60111 \\ E-mail : hendrabhakti@ymail.com ${ }^{1)}$, belasetiawan@yahoo.com ${ }^{2)}$,wisudanto@feb.unari.ac.id ${ }^{3)}$
}

\begin{abstract}
ABSTRAK
Semakin meningkatnya pertumbuhan ekonomi di Indonesia menyebabkan tingginya angka kepemilikan kendaraan oleh masyarakat. Hal ini didukung dengan masih berjalannya penjualan kendaraan bermotor dalam bentuk sepeda ataupun mobil sesuai data penjualan dari Gabungan Industri Kendaraan Bermotor Indonesia Tahun 2021. Berdasarkan kondisi tersebut, juga berpengaruh pada konsumsi bahan bakar (BBM) kendaraan bermotor. BBM seakan benar-benar menjadi kebutuhan primer setara dengan sandang, pangan dan papan yang sangat dicari oleh masyarakat. Namun demikian, hal tersebut belum didukung dengan fasilitas penjualan atau biasa disebut Satuan Pengisian Bahan Bakar Umum (SPBU) yang merata dan memadai seperti di Banyuwangi. Menindaklanjuti kondisi tersebut CV Ameera Jaya sebagai perusahaan start up melihat potensi pembangunan SPBU mikrosite sebagai prospek dalam berinvestasi. Tujuan dilakukannya penelitian ini sebagai analisis kelayakan bisnis untuk menunjang kelangsungan investasi. Dalam melakukan penelitian dilakukan pengambilan data dengan metode observasi dan wawancara serta mempelajari data menggunakan aspek hukum, aspek lingkungan, aspek pasar dan pemasaran, aspek teknis dan teknologi, aspek manajemen dan sumber daya manusia, serta aspek keuangan, Secara aspek hukum, investasi Microsite Grajagan layak dilakukan karena telah memenuhi persyaratan-persyaratan yang dibutuhkan. Secara aspek pasar dan pemasaran, investasi tersebut layak untuk dijalankan dengan estimasi omzet tahun pertama 99.180 liter atau Rp. 1.071.144.000,-. Secara aspek keuangan, payback period tercapai pada tahun ke 2 dan 9 bulan 14 hari serta Net Present Value (NPV) sebesar Rp. 494.831.444 dimana hal tersebut sudah layak untuk dilaksanakan karena maksimal payback period adalah 5 tahun dan NPV $>1$.
\end{abstract}

Kata Kunci: Investasi, Kendaraan Bermotor, Keuangan, Hukum, Pasar, SPBU

\section{PENDAHULUAN}

Semakin meningkatnya pertumbuhan ekonomi di Indonesia menyebabkan tingginya angka kepemilikan kendaraan oleh masyarakat. Hal ini didukung dengan masih berjalannya penjualan kendaraan bermotor dalam bentuk sepeda ataupun mobil.

Berdasarkan kondisi tersebut, juga berpengaruh pada konsumsi bahan bakar (BBM) kendaraan bermotor. BBM seakan benar-benar menjadi kebutuhan primer setara dengan sandang, pangan dan papan yang sangat dicari oleh masyarakat. Namun demikian, hal tersebut belum didukung dengan fasilitas penjualan atau biasa disebut Satuan Pengisian Bahan Bakar Umum (SPBU) yang merata dan memadai seperti di Banyuwangi.

Sampai dengan bulan September 2021 saja, untuk Kabupaten Banyuwangi yang membentang seluas 5.782 $\mathrm{km} 2$, dan jumlah penduduk sekitar 1,7juta jiwa hanya terdapat 26 Titik SPBU milik PT Pertamina (Persero) (https://mypertamina.id/spbu). Di samping itu, untuk wilayah Kecamatan Purwoharjo, terdapat 3 titik SPBU untuk menunjang kebutuhan sekitar 71.160 orang.

Dari data Badan Pusat Statistik Kabupaten Banyuwangi tahun 2019, jumlah motor sebanyak 6787.953 unit dan mobil penumpang 43.245 unit. Hal tersebut menunjukkan kebutuhan BBM masih sangat besar untuk operasional kendaraan, sehingga membuka potensi penjualan BBM dan juga spare part kendaraan.

Sampai dengan September 2021, PT Pertamina (Persero) masih mendominasi penyaluran BBM ke seluruh Pelosok Indonesia termasuk di Banyuwangi. Selain Pertamina, beberapa perusahaan seperti Chevron, Shell, AKR dan Exxon juga masuk dalam bisnis retail SPBU penjualan BBM namun hanya untuk area di Kota Besar seperti Surabaya dan Jakarta. Sehingga untuk beberapa daerah belum dapat di suplai secara merata.

Pada prosesnya daerah-daerah yang jauh jaraknya dari jangkauan SPBU, belum dapat merasakan suplai BBM normal karena hanya di suplai oleh penjual BBM eceran. Hal ini dimanfaatkan oleh PT Indomobil Sentra Energi untuk memasuki bisnis retail Usaha Mikro Kecil Menengah penjualan BBM di daerah-daerah yang belum terjangkau oleh Pertamina tersebut.

Sampai dengan periode September 2021, sudah berdiri sekitar 1.500 site di Pulau Jawa termasuk 17 gerai di Banyuwangi. Gerai-gerai tersebut di desain untuk ukuran area 200 meter $^{2}$ untuk menjangkau pasar yang jauh dari SPBU Konvensional.

Menindaklanjuti kondisi tersebut CV Ameera Jaya sebagai perusahaan start up melihat potensi mikrosite sebagai prospek dalam berinvestasi, sehingga diperlukan 
adanya studi kelayakan bisnis untuk menunjang kelangsungan investasi.

Sebelumnya telah dilakukan penelitian sejenis terhadap potensi kelayakan investasi sebagai berikut : Penelitian oleh (Liman et al., 2017) dengan judul Studi Kelayakan Investasi Pendirian SPBU di Monang Maning. (Rijal Arifin \& Wisudanto, 2017) melakukan penelitian tentang Crowdfunding Sebagai Alternatif Pembiayaan Pembangunan Infrastruktur, yang memberikan hasil bahwa crowdfunding dapat digunakan sebagai alternatif pembiayaan investasi. (Arianton et al., 2019)melakukan penelitian tentang studi kelayakan usaha budidaya rumput laut pada kelompok bina karya di Desa Patas, Kecamatan Gerokgak, Kabupaten Buleleng. (Rahmadani \& Makmur, 2019) melakukan penelitian tentang Analisis Studi Kelayakan Bisnis Pada Pengembangan UMKM Usaha Tahu Dan Tempe Karya Mandiri Ditinjau Dari Aspek Produksi, Aspek Pemasaran Dan Aspek Keuangan, yang memberikan hasil usaha tahu dan tempe ini dikatakan layak dengan umur proyek selama 10 tahun pada tingkat discount rate sebesar $10 \%$. (Tanaka \& Marlina, 2017) melakukan penelitian tentang Studi Kelayakan Bisnis Unique photo card Di Mal Ciputra World Surabaya yang menunjukkan hasil penelitian bahwa pengembangan bisnis Unique Photo Card untuk membuka stan di mal Ciputra World Surabaya dinyatakan layak pada tahun 2016.

Studi kelayakan bisnis atau Business Feasibility Study dapat didefinisikan sebagai suatu proses terkontrol untuk mengidentifikasi serta memahami masalah dan peluang yang akan terjadi dalam suatu proyek bisnis, menentukan tujuan, menggambarkan situasi, mendefinisikan hasil yang sukses dan menilai berbagai biaya dan manfaat yang terkait dengan beberapa alternatif untuk memecahkan masalah. Tujuan dari studi kelayakan adalah untuk menentukan apakah sebuah peluang bisnis yang diusulkan praktis, layak, dan memungkinkan untuk dilaksanakan. Ketika dihadapkan dengan peluang bisnis, banyak orang yang optimis cenderung hanya berfokus pada aspek-aspek yang positif. Sebuah studi kelayakan memungkinkan mereka untuk melihat pada kedua aspek positif dan negatif dari peluang tersebut secara nyata.

Menurut (Faradiba \& Musmulyadi, 2020) studi kelayakan bisnis tidak hanya diperlukan oleh pemrakarsa bisnis tetapi juga mampu memberikan manfaat oleh beberapa pihak yang membutuhkan kelayakan dengan berbagai kepentingan. Bagi pelaku bisnis mendapatkan manfaat dari kesimpulan studi kelayakan bisnis apakah bisnis ini layak untuk dijalankan dan investasi yang dilakukan menjanjikan, bagi investor dapat mengambil langkah apakah memasukkan modal memberikan keuntungan di masa akan datang, bagi kreditor bisa mengambil langkah memberikan kredit kepada pelaku bisnis karena kreditor dapat menganalisa berapa banyak penjualan, laba rugi yang didapatkan oleh debitur dengan begitu kredit macet dapat dihindari, sedangkan bagi pemerintah bisa mengambil langkah memberikan izin usaha ketika semua aspek penilaian dapat terpenuhi dan memberikan banyak manfaat kepada masyarakat.

Perusahaan wajib melakukan analisis terhadap kondisi pasar yang ditargetkan untuk menjadi bisnis baru, untuk mendapatkan keunggulan kompetitif atas para pesaingnya. Keunggulan kompetitif atau competitive advantage adalah keunggulan atau kelebihan suatu perusahaan dalam persaingan di pasar, yang diperoleh dengan menawarkan nilai yang lebih besar pada konsumen, baik dengan cara menetapkan harga yang lebih rendah atau dengan memberikan manfaat dan layanan yang lebih baik daripada pesaingnya. Salah satu keunggulan kompetitif suatu calon bisnis yang akan didirikan adalah jumlah penjualan yang lebih besar dari pesaing yang berada dalam pasar yang sama, karena itulah perusahaan perlu melakukan estimasi penjualan dari calon bisnis yang akan didirikan. Melalui estimasi penjualan, perusahaan akan dapat menilai potensi pasar dan perkiraan keuntungan yang dapat diperoleh saat bisnis baru tersebut resmi beroperasi secara penuh. Selain itu, estimasi penjualan perlu untuk dicantumkan dalam estimasi laba-rugi yang hasil perhitungannya dapat digunakan dalam teknik-teknik capital budgeting.

\section{RUANG LINGKUP}

Dalam penelitian ini permasalahan mencakup:

1. Cakupan permasalahan.

BBM saat ini menjadi kebutuhan pokok dikalangan masyarakat. Hampir seluruh kegiatan dilakukan menggunakan kendaraan bermotor yang membutuhkan konsumsi BBM yang tidak sedikit. Khususnya di daerah Banyuwangi dengan padatnya jumlah penduduk tetapi tidak didukung dengan fasilitas SPBU yang mencukupi. Hal tersebut mendukung CV Ameera Jaya untuk masuk ke dunia usaha SPBU.

Penelitian dilakukan bertujuan untuk mengetahui kelayakan investasi mikrosite Indomobil yang dilakukan CV Ameera Jaya. Oleh karena itu, kelayakan investasi ini akan dianalisis berdasarkan kepadatan jumlah kendaraan di Desa Grajagan.

2. Batasan-batasan penelitian.

Batasan masalah yang digunakan dalam penelitian ini adalah Perusahaan yang akan dianalisis adalah CV Ameera Jaya dengan wilayah penelitian hanya dibatasi pada Desa Grajagan. Kriteria yang digunakan adalah jumlah kepadatan kendaraan berdasarkan survey.

3. Rencana hasil yang didapatkan.

Rencana hasil yang didapatkan adalah keberhasilan investasi mikrosite Indomobil dalam jangka pendek maupun jangka panjang. Selain itu tetap menjaga lingkungan di Desa Grajagan tidak mengalami pencemaran akibat kegiatan usaha tersebut. 


\section{BAHAN DAN METODE}

Berikut teori-teori yang disampaikan oleh beberapa penelitian sebelumnya, serta metode yang digunakan dalam menganalisa kelayakan investasi atas data yang telah diambil :

\subsection{Investasi}

Investasi adalah suatu kegiatan yang menempatkan beberapa atau sebagian besar uang dengan harapan memperoleh manfaat maupun keuntungan dalam jangan pendek atau jangka panjang. Kegiatan investasi dipengaruhi beberapa hal, diantara lain tingkat keuntungan dan faktor risikonya. Seseorang yang ingin melakukan investasi harus memiliki pemahaman yang baik terhadap faktor risiko yang akan terjadi bila kegiatan investasi tidak berjalan dengan lancar.

Semakin bertambahnya kebutuhan manusia setiap harinya juga akan mempengaruhi manusia tersebut untuk melakukan investasi, dengan kata lain investasi adalah tabungan untuk masa depan. Investasi dapat dilakukan berupa aset nyata maupun aset finansial. Aset nyata berupa property ataupun benda-benda yang memiliki pertambahan nilai di masa mendatang, sedangkan aset finansial seperti saham, reksa dana, deposito dan lainlain.

Keputusan investasi merupakan minat seseorang yang sukarela dengan sengaja mencadangkan uang yang dia miliki saat ini ke dalam sebuah aset investasi untuk diharapkan dapat memberikan keuntungan di masa depan. Begitu pula dengan yang dilakukan oleh seorang pengusaha apabila dia ingin menghasilkan manfaat yang lebih besar terhadap yang dia miliki saat ini maka dia perlu melakukan investasi. Investasi dapat dilakukan pada berbagai pilihan aset real seperti tanah, mesin, rumah atau pada aset keuangan pada saham, obligasi dan surat berharga lainnya.

Menurut (Sugiyanto et al., 2020), aspek-aspek yang perlu dikaji dalam studi kelayakan bisnis adalah Aspek Hukum, Aspek Lingkungan, Aspek Pasar dan Pemasaran, Aspek Teknis dan Teknologi, Aspek Manajemen dan Sumber Daya Manusia, serta Aspek Keuangan. Tujuan dari mempelajari aspek-aspek tersebut adalah untuk memeroleh kesimpulan yang kuat mengenai dijalankan atau tidaknya sebuah rencana bisnis.

Menurut (Agung \& Yuesti, 2019) penelitian deskriptif adalah penelitian yang dilakukan untuk mengetahui nilai variable mandiri, baik satu variabel maupun lebih (independen) tanpa membuat perbandingan, atau menghubungkan dengan variabel yang lain. Penelitian ini melakukan studi terhadap suatu kasus tertentu secara spesifik, yang merupakan karakteristik dari bentuk penelitian deskriptif. Metode deskriptif bertujuan untuk menjelaskan secara sistematis, faktual, dan akurat mengenai fakta dan karakteristik populasi atau hal tertentu.

Hal tersebut senada dengan pernyataan (Arianti, 2018), (Herdjiono \& Damanik, 2016), dan (Susdiani,
2017) dimana penelitiannya menunjukkan literasi keuangan tidak mempengaruhi keputusan investasi.

\subsection{Metode Analisis Kelayakan Investasi}

Metode pengumpulan data yang digunakan dalam penelitian ini adalah wawancara tatap muka (personal interview) dan observasi, di mana peneliti melakukan pengumpulan data dengan cara mengadakan komunikasi langsung dengan pemilik proyek dan melakukan pengamatan langsung pada proyek.

Menurut (Sugiyanto et al., 2020) aspek-aspek yang perlu dikaji dalam studi kelayakan bisnis adalah Aspek Hukum, Aspek Lingkungan, Aspek Pasar dan Pemasaran, Aspek Teknis dan Teknologi, Aspek Manajemen dan Sumber Daya Manusia, serta Aspek Keuangan.

Menurut (Purnomo et al., 2017) dalam aspek hukum, penilaian dilakukan dengan melakukan checklist kelengkapan dokumen hukum perusahaan seperti Nomor Pokok Wajib Pajak (NPWP), Nomor Induk Berusaha (NIB), Izin lokasi, Izin Mendirikan Bangunan (IMB ), Izin Lingkungan, Surat Izin Usaha Perdagangan (SIUP).

Beberapa hal yang perlu dipertimbangkan sesuai aspek teknis adalah lokasi bisnis, layout bisnis dan peralatan atau teknologi yang digunakan. Begitu juga untuk aspek pasar perlu dilakukan analisis terkait jumlah calon konsumen yang berada di sekitar lokasi bisnis dimana hal-hal tersebut dilakukan untuk mengetahui potensi penjualan akan menguntungkan atau tidak.

Dalam aspek manajemen dan sumber daya manusia, dievaluasi proses monitoring pegawai dan penjualan untuk mengontrol kedisiplinan. Selain itu juga dievaluasi terkait tingkat pendidikan dan pelatihan-pelatihan yang diberikan guna mengoptimalkan potensi pegawai serta meminimalisasi adanya kecurangan.

Terdapat beberapa metode yang biasa digunakan dalam menganalisa kelayakan investasi :

\section{1. $\quad$ Metode Payback Period (PP)}

Payback period adalah periode yang diperlukan untuk dapat menutup kembali pengeluaran investasi dengan menggunakan aliran kas neto (net cash flows) (Purnomo et al., 2017).

$$
P P=\frac{\text { Investasi }}{\text { Cash Flow }} \times 1 \text { tahun }
$$

Investasi dikatakan layak jika nilai payback period lebih kecil dibandingkan dengan target kembalinya investasi.

\section{2. $\quad$ Metode Net Present Value (NPV)}

Net present value adalah selisih present value dari keseluruhan proceed dengan present value dari keseluruhan investasi (Purnomo et al., 2017)

$$
N P V=-k_{t}+\frac{b_{1}-c_{1}}{(1+i)}+\cdots+\frac{b_{n}-c_{n}}{(1+i)^{n}}
$$

Dimana NPV adalah nilai sekarang bersih, $-\mathrm{k}_{\mathrm{t}}$ adalah capital yang digunakan pada periode investasi, $b_{1}$, ..... $b_{n}$ adalah penerimaan pada tahun ke-1 sampai pada 
tahun ke-n, $\mathrm{c}_{1}, \ldots . \mathrm{c}_{\mathrm{n}}$ adalah pengeluaran pada tahun ke1 sampai pada tahun ke-n dan i adalah tingkat discount rate.

Jika nilai NPV lebih besar dari 0 maka investasi dikatakan layak, jika lebih kecil dari 0 maka investasi dikatakan tidak layak.

Gambar 1 menunjukkan bahwa alur sistem perhitungan dalam menganalisa kelayakan investasi.



\section{Gambar 1. Alur Sistem}

\section{PEMBAHASAN}

Berdasarkan data yang diperoleh dari CV Ameera Jaya maka hasil penelitian sebagai berikut :

\subsection{Aspek Hukum}

Bentuk usaha dari SPBU Microsite Grajagan adalah Commanditaire Venootschap (CV), yang dikelola dengan modal dari pendiri perusahaan. Dokumendokumen yang diperlukan dalam perizinan perusahaan adalah Nomor Pokok Wajib Pajak (NPWP), Nomor Induk Berusaha (NIB), Izin lokasi, Izin Mendirikan Bangunan (IMB), Izin Lingkungan, Surat Izin Usaha Perdagangan (SIUP). Penilaian aspek hukum dilakukan meminimalisasikan masalah hukum atau tidak diperolehnya izin dari pemerintah setempat.

Tabel 1 Aspek Hukum

\begin{tabular}{ccc}
\hline Uraian & Ada & Tidak Ada \\
\hline NPWP & V & - \\
\hline NIB & V & - \\
\hline IMB & V & - \\
\hline SIUP & V & - \\
\hline
\end{tabular}

Sumber : CV Ameera Jaya (2021)
Tabel 1 menunjukkan bahwa, perusahaan mampu untuk memperoleh dokumen-dokumen dan persyaratan yang dibutuhkan sehingga aspek ini dapat dikatakan layak untuk dijalankan.

\subsection{Aspek Pasar dan Pemasaran}

Dampak informasi lokasi dari stasiun pengisian bahan bakar pesaing dalam menentukan harga bahan bakar di Microsite dianalisis. Perkiraan dari penelitian tersebut menunjukkan bahwa semakin banyak stasiun yang berdekatan meningkatkan tekanan dalam persaingan, dan dengan demikian harga bahan bakar akan turun. Berdasarkan survei terdapat 2 SPBU terdekat dan 1 SPBU mikro Pertashop dengan mengabaikan pedagang BBM eceran.

Peneliti juga telah melakukan pengambilan sampling data kepadatan lalu lintas dilakukan pada tanggal 02 Oktober 2021 sampai dengan 08 Oktober 2021 dengan rata-rata data sebagai berikut :

Tabel 2. Kepadatan Lalu Lintas

\begin{tabular}{ccccc}
\hline \multirow{2}{*}{ No } & \multicolumn{2}{c}{ Jam } & \multicolumn{2}{c}{ Jenis Kendaraan (Unit) } \\
\cline { 2 - 5 } $\mathbf{1}$ & Mulai & Selesai & Motor & Mobil \\
\hline $\mathbf{2}$ & 06.00 & 07.00 & 300 & 40 \\
\hline $\mathbf{3}$ & 07.00 & 08.00 & 159 & 2 \\
\hline $\mathbf{4}$ & 09.00 & 09.00 & 201 & 10 \\
\hline $\mathbf{5}$ & 10.00 & 11.00 & 71 & 2 \\
\hline $\mathbf{6}$ & 11.00 & 12.00 & 80 & 10 \\
\hline $\mathbf{7}$ & 12.00 & 13.00 & 93 & 3 \\
\hline $\mathbf{8}$ & 13.00 & 14.00 & 116 & 6 \\
\hline $\mathbf{9}$ & 14.00 & 15.00 & 99 & 11 \\
\hline $\mathbf{1 0}$ & 15.00 & 16.00 & 105 & 9 \\
\hline $\mathbf{1 1}$ & 16.00 & 17.00 & 215 & 17 \\
\hline $\mathbf{1 2}$ & 17.00 & 18.00 & 290 & 35 \\
\hline $\mathbf{1 3}$ & 18.00 & 19.00 & 350 & 24 \\
\hline $\mathbf{1 4}$ & 19.00 & 20.00 & 110 & 10 \\
\hline $\mathbf{1 5}$ & 20.00 & 21.00 & 90 & 7 \\
\hline & Total & & $\mathbf{2 . 5 5 3}$ & $\mathbf{1 9 5}$ \\
\hline & Sumber : CV Ameera Jaya (2021) \\
\hline
\end{tabular}

Tabel 2 menunjukkan bahwa survey kepadatan lalu lintas dimulai dari pukul 06.00 WIB - 21.00 WIB yang memberikan hasil rata-rata sebanyak 2.553 sepeda motor dan 195 mobil yang melalui Jalan Raya Sumber Asri dimana lokasi Microsite Grajagan berada.

Estimasi potensi omzet dengan menargetkan 5\% dari jumlah kendaraan yang lewat maka didapatkan :

Pembelian BBM : 5\% × 2.553 unit $\times 2$ liter $=256$ liter/day dengan kondisi sepeda motor didominasi jenis sepeda motor bebek. 
Pembelian BBM : $1 \%$ x 195 unit x 10 liter $=19,5$ liter/day dengan kondisi mobil didominasi jenis mobil MPV. Sehingga penjualan BBM per bulan sebanyak 8.265 liter.

Berdasarkan proposal investasi dari PT Indomobil Sentra Niaga menargetkan penjualan \pm 6000 liter pada bulan pertama dengan kenaikan penjualan mengingat pada fase awal pembukaan merupakan pengenalan produk pada pasar. Sehingga dalam hal ini mengacu terhadap survei potensi pasar, investasi tersebut layak untuk dijalankan dengan estimasi omzet tahun pertama 99.180 liter atau Rp. 1.071.144.000,-.

\subsection{Aspek Teknis dan Teknologi}

Usaha Microsite Grajagan ini akan didirikan di atas merupakan tanah sewa yang beralamat di Jalan Raya Sumber Asri RT.1 RW.2 Dusun Curah Jati Desa Grajagan Kecamatan Purwoharjo Kabupaten Banyuwangi. Pemilik usaha menyediakan bangunan seluas $250 \mathrm{~m} 2$ yang akan digunakan untuk menjalankan operasi perusahaan, di mana biaya pembangunan SPBU microsite adalah sebesar Rp. 175.000.000. Lokasi Microsite Grajagan yang digunakan berada pada jalan desa yang menghubungkan antara beberapa desa yang masyarakatnya lewati apabila terdapat keperluan di kota. Jalan desa tersebut memiliki lebar 6 meter. Layout bangunan SPBU didesain oleh tim dari PT Indomobil Sentra Niaga selaku mitra bisnis dimana hal tersebut sudah mempertimbangkan pengalaman pembangunan SPBU microsite sebelumnya sehingga dapat mengoptimalkan area yang ada.

Di samping itu berdasarkan proposal investasi, PT Indomobil Sentra Niaga meminjamkan dispenser 2 noze, 1 set alat pemadam kebakaran, dengan tangki BBM duduk yang menyatu dengan dispenser beserta container penjualan spare part kendaraan roda dua menggunakan sistem deposit pada CV Ameera Jaya sebagai penunjang dalam kegiatan operasional. Kedua belah pihak perusahaan juga sepakat mengasuransikan Microsite Grajagan dari kecelakaan-kecelakaan yang dimungkinkan terjadi.

Menindaklanjuti aspek teknis dan teknologi, proyek ini dapat dilanjutkan karena telah tersedianya lokasi yang strategis dan mudah diakses serta peralatan yang diperlukan telah sesuai dengan teknologi yang dibutuhkan.

\subsection{Aspek Manajemen dan Sumber Daya Manusia}

Dalam mengelola jalannya operasional Microsite Grajagan, dilakukan bersama-sama antara PT Indomobil Sentra Niaga dan CV Ameera Jaya. Proses absensi operator dan laporan penjualan, dilakukan dengan sistem online yang melapor dalam grup pada aplikasi Whatsapp yang berisi personil dari PT Indomobil Sentra Niaga dan CV Ameera Jaya. Operator yang dipekerjakan merupakan lulusan SMK Penjualan dengan pembekalan pelatihan operasional SPBU dan mekanik dasar oleh PT Indomobil Sentra Niaga selama 1 minggu sebelum aktif bekerja. Adapun SDM tersebut merupakan warga lokal guna memudahkan pemantauan dan memberdayakan potensi sumber daya daerah.

Berdasarkan hal tersebut merujuk pada aspek manajemen dan sumber daya manusia proyek ini dapat dijalankan karena telah tersedianya sistem manajemen tersentralisasi antara kedua belah perusahaan.

\subsection{Aspek Keuangan}

Aspek keuangan adalah aspek terakhir namun paling penting dalam studi kelayakan bisnis, karena hasil perhitungan dari aspek inilah yang akan mendapatkan perhatian utama dari setiap investor.

Untuk mendanai proyek investasi Microsite Grajagan ini, diperlukan investasi awal (initial cash flow) sebesar Rp. 175.000.000,-. Investasi tersebut sudah meliputi sewa tanah, bangunan, WC, sumur, bahan kelistrikan, peralatan operasional, peralatan administrasi, dan biaya lainnya yang akan menunjang kelangsungan kegiatan usaha Microsite Grajagan. Dana untuk investasi proyek ini seluruhnya terdiri dari modal sendiri yang diperoleh dari perusahaan, sehingga pada perhitungan Net Present Value (NPV), Discount Factor yang digunakan adalah bunga deposito sebesar 2,45 persen menggunakan rate deposito Bank BCA periode 19 Oktober 2021, dengan dua pertimbangan apakah investor akan menggunakan dana tersebut untuk investasi dalam proyek Microsite Grajagan atau menyimpan dana tersebut dalam bentuk deposito di bank.

Tabel 3. Nilai Sisa (Dalam Ribu)

\begin{tabular}{cccccc}
\hline $\begin{array}{c}\text { Jenis } \\
\text { Aktiva } \\
\text { Tetap }\end{array}$ & $\begin{array}{c}\text { Umur } \\
\text { Eko } \\
\text { (Th) }\end{array}$ & $\begin{array}{c}\text { Harga } \\
\text { Perolehan }\end{array}$ & $\begin{array}{c}\text { Biaya } \\
\text { Depresiasi } \\
\text { / Tahun }\end{array}$ & $\begin{array}{c}\text { Akumulasi } \\
\text { Depresiasi }\end{array}$ & $\begin{array}{c}\text { Nilai } \\
\text { Sisa } \\
\text { Setelah } \\
\text { Tahun } \\
\text { ke 10 }\end{array}$ \\
\hline $\begin{array}{c}\text { Tanah } \\
\text { (Sewa) }\end{array}$ & - & - & - & - & - \\
\hline Bangunan & 10 & 125.000 & 12.500 & 125.000 & - \\
\hline $\begin{array}{l}\text { Peralatan } \\
\text { Penjualan }\end{array}$ & 10 & - & - & - & - \\
\hline $\begin{array}{l}\text { Peralatan } \\
\text { Adm. }\end{array}$ & 10 & 4.500 & 450 & 4.500 & - \\
\hline $\begin{array}{c}\text { Franchise } \\
\text { Fee }\end{array}$ & 3 & 45.000 & 15.000 & 45.000 & - \\
\hline Total Nilai Sisa & Sumber : CV Ameera Jaya (2021)
\end{tabular}

Tabel 3 menunjukkan bahwa total nilai sisa pada Microsite Grajagan sebesar Rp. 27.950.000,-.

Sesuai perjanjian kontrak franchise, PT Indomobil memotong pajak PPH 21 sebesar 2,5\% setiap bagi hasil penjualan bulanan sehingga akumulasi nilai pajak sesuai estimasi omzet hasil survey sekitar 99.180 liter sebesar Rp. 2.479.500,-.

Dari proyeksi laba/rugi Microsite Grajagan tersebut, dapat diperoleh aliran kas operasional atau proceeds setiap tahunnya sebagai berikut: 
Tabel 4. Proyeksi Laba Rugi

\begin{tabular}{cccc}
\hline Tahun & Proceeds & Tahun & Proceeds \\
\hline $\mathbf{2 0 2 1}$ & 17.150 .500 & $\mathbf{2 0 2 6}$ & 93.218 .485 \\
\hline $\mathbf{2 0 2 2}$ & 91.795 .000 & $\mathbf{2 0 2 7}$ & 75.155 .409 \\
\hline $\mathbf{2 0 2 3}$ & 101.560 .000 & $\mathbf{2 0 2 8}$ & 86.939 .180 \\
\hline $\mathbf{2 0 2 4}$ & 83.914 .000 & $\mathbf{2 0 2 9}$ & 83.562 .139 \\
\hline $\mathbf{2 0 2 5}$ & 96.135 .700 & $\mathbf{2 0 3 0}$ & 75.016 .246 \\
\hline \multicolumn{4}{l}{ Sumber : CV Ameera Jaya (2021) }
\end{tabular}

Tabel 4 memperlihatkan proyeksi laba rugi pada Microsite Grajagan dimana pada tahun 2017 diperoleh nilai laba tertinggi sebesar Rp. 101.560.000,-.

\section{Payback Period}

Merujuk pada persamaan (1), serta proyeksi laba rugi pada Tabel 4, maka periode pengembalian investasi SPBU Microsite Grajagan sebagai berikut :

$$
\begin{array}{ll}
\text { Initial cash flow } & =\operatorname{Rp} 175.000 .000,- \\
\text { Proceed tahun ke-1 } & =\operatorname{Rp} 17.150 .000,-(-) \\
& =\operatorname{Rp} 157.849 .500,- \\
\text { Proceed tahun ke-2 } & \equiv \operatorname{Rp} 91.795 .000,-(-) \\
& =\operatorname{Rp} 66.054 .500,-
\end{array}
$$

\section{Sehingga :}

$$
\begin{aligned}
& \text { Payback Period }=2 \text { tahun }+ \\
& \frac{R p \text { 66.054.500,- }}{R p 101.560 .000,-} \times 360 \text { hari } \\
& =2 \text { tahun, } 7 \text { bulan dan } 25 \text { hari }
\end{aligned}
$$

Dari perhitungan pada persamaan (6), maka dapat dilihat bahwa Payback Period dari investasi Microsite Grajagan ini adalah 2 tahun 7 bulan 25 hari. Payback maksimum adalah 5 tahun, namun payback period-nya adalah sejumlah 2 tahun 7 bulan 25 hari. Hal ini berarti bahwa payback period waktunya lebih singkat jika dibandingkan dengan periode payback maksimum, sehingga usulan investasi dianggap layak untuk diterima.

\section{Net Present Value}

Berdasarkan perhitungan NPV mengacu pada estimasi cash flow 10 tahun di atas, maka NPV sebagai berikut:

$$
\begin{aligned}
& N P V=-k_{t}+\frac{b_{1}-c_{1}}{(1+i)}+\cdots+\frac{b_{n}-c_{n}}{(1+i)^{n}} \\
& \mathrm{NPV}=\mathrm{Rp} .539 .380 .917
\end{aligned}
$$

Berdasarkan perhitungan pada persamaan (7), dapat dikatakan bahwa pembangunan Microsite Grajagan layak untuk dilaksanakan karena nilai NPV $>1$.

\section{KESIMPULAN}

Merujuk pada pembahasan, investasi layak dilakukan karena telah memenuhi persyaratan-persyaratan yang dibutuhkan. Secara aspek pasar dan pemasaran, investasi tersebut layak untuk dijalankan dengan estimasi omzet tahun pertama 99.180 liter atau Rp. 1.071.144.000,-. Secara aspek teknis dan teknologi, investasi ini dapat dilanjutkan karena telah tersedianya lokasi yang strategis dan mudah diakses, desain layout dari tim yang berpengalaman serta peralatan yang diperlukan telah sesuai dengan teknologi yang dibutuhkan. Secara aspek manajemen, investasi ini dapat dijalankan karena telah tersedianya sistem manajemen tersentralisasi antara kedua belah perusahaan di samping itu, tingkat pendidikan operator sudah mencukupi karena lulusan SMK disertai pelatihan secara berkala untuk mengoptimalkan kinerja operator. Secara aspek keuangan, payback period tercapai pada tahun ke 2 dan 7 bulan 25 hari serta NPV sebesar Rp. 539.380.917 dimana hal tersebut sudah layak untuk dilaksanakan karena maksimal payback period adalah 5 tahun dan NPV $>1$.

Berdasarkan beberapa aspek yang telah diteliti maka Microsite Grajagan merupakan investasi yang layak untuk dilanjutkan.

\section{SARAN}

Untuk penelitian selanjutnya peneliti dapat menggunakan aspek-aspek pendekatan lain seperti analisis Porter's Five Model untuk menilai keunggulan rekanan supplier hingga potensi pasar agar dapat melihat celah dalam membuat nilai tambah atas produk yang didistribusikan kepada pelanggan atau metode pemasaran $5 \mathrm{P}$ dimana hal tersebut sangat cocok untuk bisnis UMKM.

Evaluasi nilai tambah produk digunakan untuk mengetahui nilai output dan produktivitas serta besar balas jasa terhadap pemilik faktor produksi (Berlia et al., 2017).

\section{DAFTAR PUSTAKA}

Agung, A. P. A., \& Yuesti, A. (2019). Metode Penelitian Bisnis Kuantitatif Dan Kualitatif (I. S. Nengah, Ed.; 1st ed.). CV. Noah Aletheia.

Arianti, B. F. (2018). The Influence Of Financial Literacy, Financial Behavior and Income On Investment Decision. Economics and Accounting Journal, 1(1).

Arianton, K., Meitriana, M. A., \& Haris, I. A. (2019). Studi Kelayakan Usaha Budidaya Rumput Laut Pada Kelompok Bina Karya Di Desa Patas, Kecamatan Gerokgak, Kabupaten Buleleng. Jurnal Pendidikan Ekonomi, 11(2), 573-582.

Berlia, M., Gumilar, I., Yuliadi, L. P. S., \& Nurhayati, A. (2017). Analisis Usaha Dan Nilai Tambah Produk Kerupuk Berbahan Baku Ikan Dan Udang (Studi Kasus Di Perusahaan Sri Tanjung Kabupaten Indramayu). Jurnal Perikanan Dan Kelautan, $\operatorname{VIII}(2), 118-125$.

Faradiba, B., \& Musmulyadi. (2020). Analisis Studi Kelayakan Bisnis Usaha Waralaba Dan Citra Merek Terhadap Keputusan Pembelian Alpukat Kocok-Doubig Di Makassar. PAY Jurnal Keuangan Dan Perbankan, 2(2), 52-61. 
Gabungan Industri Kendaraan Bermotor Indonesia. (2021, November 15). Indonesian Automobile Industry

Data.

Https://Www.Gaikindo.or.Id/Indonesian-

Automobile-Industry-Data/.

https://www.gaikindo.or.id/indonesian-automobileindustry-data/

Herdjiono, I., \& Damanik, L. A. (2016). Pengaruh Financial Attitude, Financial Knowledge, Parental Income Terhadap Financial Management Behavior. Jurnal Manajemen Teori Dan Terapan, 9(3), 226241.

Liman, R. M., Agung, A., \& Suarjaya, G. (2017). Studi Kelayakan Investasi Pendirian SPBU Di MonangManing. E-Jurnal Manajemen Unud, 6(10), 54895523.

Purnomo, R. A., Riawan, \& Sugiyanto, L. ode. (2017). Studi Kelayakan Bisnis (1st ed., Vol. 1). Unmuh Ponorogo Press.

Rahmadani, S., \& Makmur. (2019). Analisis Studi Kelayakan Bisnis Pada Pengembangan UMKM Usaha Tahu Dan Tempe Karya Mandiri Ditinjau Dari Aspek Produksi, Aspek Pemasaran Dan Aspek Keuangan. HIRARKI: Jurnal Ilmiah
Manajemen Dan Bisnis, 1(1), 76-83. http://journal.upp.ac.id/index.php/Hirarki

Rijal Arifin, S., \& Wisudanto. (2017). Crowdfunding Sebagai Alternatif Pembiayaan Pembangunan Infrastruktur. Prosiding Simposium II - UNIID, 309-314.

Sugiyanto, Nadi, L., \& Wenten, I. K. (2020). Studi Kelayakan Bisnis (G. S. Nuke, Ed.; 1st ed., Vol. 1). Yayasan Pendidikan dan Sosial Indonesia Maju (YPIM).

Susdiani, L. (2017). Pengaruh Financial Literacy dan Financial Experience Terhadap Perilaku Perencanaan Investasi PNS Di Kota Padang Influence of Financial Literacy and Financial Experience to Behavior of Investment Planning of PNS In Padang City. Journal Pembangunan Nagari, 2(1), 61-74.

Tanaka, L. A., \& Marlina, M. A. E. M. (2017). Studi Kelayakan Bisnis Unique Photocard Di Mal Ciputra World Surabaya. PERFORMA: Jurnal Manajemen Dan Start-Up Bisnis, 1(6), 746-754. 